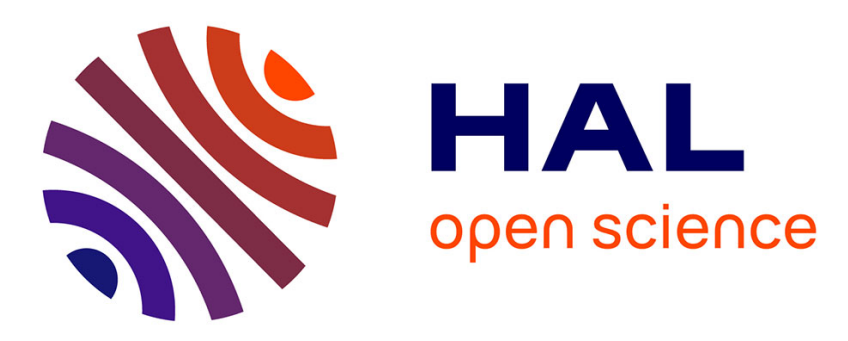

\title{
Landscape consequences of aggregation rules for functional equivalence in compensatory mitigation programs
}

Francesco Accatino, Irena Creed, Marian Weber

\section{- To cite this version:}

Francesco Accatino, Irena Creed, Marian Weber. Landscape consequences of aggregation rules for functional equivalence in compensatory mitigation programs. Conservation Biology, 2018, 32 (3), pp.694-705. 10.1111/cobi.13084 . hal-02621253

\section{HAL Id: hal-02621253 \\ https://hal.inrae.fr/hal-02621253}

Submitted on 26 May 2020

HAL is a multi-disciplinary open access archive for the deposit and dissemination of scientific research documents, whether they are published or not. The documents may come from teaching and research institutions in France or abroad, or from public or private research centers.
L'archive ouverte pluridisciplinaire HAL, est destinée au dépôt et à la diffusion de documents scientifiques de niveau recherche, publiés ou non, émanant des établissements d'enseignement et de recherche français ou étrangers, des laboratoires publics ou privés. 


\title{
Landscape consequences of aggregation rules for functional equivalence in compensatory mitigation programs
}

\author{
Francesco Accatino, ${ }^{1} \dagger$ Irena F. Creed iD $, 1,2 *$ and Marian Weber ${ }^{3}$ \\ ${ }^{1}$ Department of Biology, Western University, 1151 Richmond Street N., London, ON N6A 5B7, Canada \\ ${ }^{2}$ School of Environment and Sustainability, 329 Kirk Hall, 117 Science Place, Saskatoon, SK S7N 5C8, Canada \\ ${ }^{3}$ Alberta Innovates, 250 Karl Clark Road, Edmonton, AB T6N 1E4, Canada
}

\begin{abstract}
Mitigation and offset programs designed to compensate for ecosystem function losses due to development must balance losses from affected ecosystems with gains in restored ecosystems. Aggregation rules applied to ecosystem functions to assess site equivalence are based on implicit assumptions about the substitutability of functions among sites and can profoundly influence the distribution of restored ecosystem functions on the landscape. We investigated the consequences of rules applied to the aggregation of ecosystem functions for wetland offsets in the Beaverbill watershed in Alberta, Canada. We considered the fate of 3 ecosystem functions: bydrology, water purification, and biodiversity. We set up an affect-and-offset algorithm to simulate the effect of aggregation rules on ecosystem function for wetland offsets. Cobenefits and tradeoffs among functions and the constraints posed by the quantity and quality of restorable sites resulted in a redistribution of functions between affected and offset wetlands. Hydrology and water purification functions were positively correlated with one another and negatively correlated with biodiversity function. Weightedaverage rules did not replace functions in proportion to their weights. Rules prioritizing biodiversity function led to more monofunctional wetlands and landscapes. The minimum rule, for which the wetland score was equal to the worst performing function, promoted multifunctional wetlands and landscapes. The maximum rule, for which the wetland score was equal to the best performing function, promoted monofunctional wetlands and multifunctional landscapes. Because of implicit trade-offs among ecosystem functions, no-netloss objectives for multiple functions should be constructed within a landscape context. Based on our results, we suggest criteria for the design of aggregation rules for no net loss of ecosystem functions within a landscape context include the concepts of substitutability, cobenefits and trade-offs, landscape constraints, beterogeneity, and the precautionary principle.
\end{abstract}

Keywords: area, compensation, ecosystem services, equivalence, function, restoration, wetland

Consecuencias Paisajísticas de las Reglas de Agregación para la Equivalencia Funcional en los Programas de Mitigación Compensatoria

Resumen: La mitigación y los programas de compensación diseñados para contrarrestar la pérdida de servicios ambientales causada por el desarrollo deben balancear las pérdidas en los ecosistemas afectados y las ganancias en los ecosistemas restaurados. Las reglas de agregación aplicadas a las funciones de los ecosistemas para evaluar la equivalencia de sitio están basadas en suposiciones implícitas sobre lo reemplazable de las funciones entre sitios y pueden influenciar profundamente la distribución de las funciones de los ecosistemas restaurados en el paisaje. Investigamos las consecuencias de las reglas aplicadas a la agregación de las funciones ambientales para las compensaciones de bumedales en la cuenca de Beaverbill en Alberta, Canadá. Consideramos el destino de tres funciones ambientales: bidrología, purificación de agua y biodiversidad.

*email irena.creed@usask.ca

†Current address: UMR SADAPT, INRA, AgroParisTech, Université Paris-Saclay, 16 rue Claude Bernard 75005 , Paris, France Article impact statement: Offsetting aggregation rules must consider substitutability, cobenefits, trade-offs, landscape constraints, and beterogeneity and be precautionary.

Paper submitted October 18, 2016; revised manuscript accepted December 5, 2017. 
Establecimos un algoritmo de afectar-y-compensar para simular el efecto de las reglas de agregacion sobre las funciones del ecosistema para las compensaciones de los bumedales. Los co-beneficios y las compensaciones entre las funciones y restricciones presentadas por la cantidad y la calidad de los sitios restaurables resultaron en una redistribución de funciones entre los humedales afectados y los compensados. La hidrología y las funciones de purificación de agua estuvieron correlacionadas positivamente entre sí y correlacionadas negativamente con la función de biodiversidad. Las reglas de promedio ponderado no remplazaron a las funciones en proporción a su importancia. Las reglas que priorizan la función de biodiversidad resultaron en humedales y paisajes más monofuncionales. La regla mínima, para la cual el puntaje del bumedal era igual a la función con el peor desempeño, promovió bumedales y paisajes multifuncionales. La regla máxima, para la cual el puntaje del humedal era igual a la función con el mejor desempeño, promovió bumedales monofuncionales y paisajes multifuncionales. Debido a las compensaciones implícitas entre las funciones ambientales, se deberían construir objetivos sin pérdida neta para funciones múltiples dentro de un contexto paisajístico. Con base en nuestros resultados, sugerimos que los criterios para el diseño de reglas de agregación para evitar la pérdida neta de funciones ambientales dentro de un contexto paisajístico incluyan los conceptos de sustentabilidad, co-beneficios y compensaciones, restricciones paisajísticas, beterogeneidad, y el principio de precaución.

Palabras Clave: área, compensación, equivalencia, función, humedal, restauración, servicios ambientales

摘要: 为弥补发展导致的生态系统功能丧失而设计的减缓和补偿计划必须平衡受影响的生态系统的损失及已 恢复的生态系统的收益。应用于生态系统功能补偿、评估不同位点等效性的聚合规则建立在位点之间功能可 替代性的假设之上, 对所恢复的生态系统功能在景观水平上的分布有深远影响。我们探究了加拿大阿尔伯塔省 Beaverhill 流域湿地补偿计划中, 将聚合规则用于生态系统功能补偿所产生的效果。我们考虑三类生态系统功 能的变化: 水文、水体净化和生物多样性。我们建立了一个影响 补偿算法, 来模拟聚合规则在湿地补偿计划中 对生态系统功能的作用。结果表明, 生态系统功能之间的协同效益和利弊权衡, 以及可恢复位点的数量和质量所 产生的制约, 导致了受影响的湿地和补偿计划的湿地生态系统功能的再分配。比如水文功能与生物多样性功能 正相关, 而水体净化功能与之成负相关。加权平均的规则并没有根据功能的权重进行功能的替代。优先考虑生 物多样性功能的规则导致湿地和景观功能单一化。如最小规则, 即湿地的评分基于表现最差的功能特征, 促进了 湿地和景观功能的多样化。最大规则, 即湿地的评分基于表现最优的功能特征, 则促进了湿地功能的单一化和景 观功能的多样化。由于生态系统功能之间隐含的利弊权衡, 多个功能无净损失的目标应该构建在景观水平上。 基于我们的结果, 我们建议在景观水平上, 生态系统功能无净损失的聚合规则的设计标准应该包含可替代性、协 同效益和利弊权衡、景观限制、异质性和预警原则的概念。【翻译: 胡怡思; 审校: 聂永刚】

关键词: 湿地, 地区, 功能, 补偿, 恢复, 等效性, 生态系统服务

\section{Introduction}

Urban and agricultural expansion is causing the progressive removal of natural ecosystems (Metzger et al. 2006). Compensatory mitigation and offset programs address losses of ecosystem functions through protection, enhancement, and restoration of ecosystems (Nunez-Mir et al. 2015). The policy goal of no net loss of ecosystem functions is central to offsetting; however, defining no net loss is one of the most contentious aspects of offset policy (BBOP 2012; ICMM IUCN 2013). With over 100 offset programs in place or in development worldwide (OECD 2016), the development of criteria for establishing equivalence among complex functional components of ecosystems between sites affected by development and sites that are restored is important to ensuring conservation outcomes under offset policies (e.g., Bull et al. 2016). The aggregation of multiple ecosystem functions in equivalence rules can lead to the substitution of functional components between sites and changes in the distribution of ecosystem functions on landscapes when offset policies are scaled up at regional and national lev- els (Thomas \& Lamb 2005). Understanding the implications of equivalence rules for the evolution of ecosystem functions over space and time is important to ensuring offsets avoid unintended consequences and contribute to resilient landscapes.

Area-based no-net-loss policies, such as those applied in the early days of wetland compensation under the U.S. Clean Water Act, ignored the loss of important ecosystem functions, such as flood mitigation and water purification, and the impacts on people who benefited from them (Ruhl et al. 2009). Offset programs are increasingly moving away from area-based no-net-loss objectives toward function-based no-net-loss objectives (Jacob et al. 2016). For example, offset programs will help achieve the European Union's no-net-loss targets for ecosystem services. To achieve no net loss of ecosystem functions, offset programs require appropriate metrics and aggregation rules for combining functions to assess equivalence between affected and restored sites and have given rise to a variety of approaches (e.g., Rayment 2014).

There are no agreed-upon best practices for aggregating ecosystem functions. Aggregation rules are ad hoc 
and reflect a combination of scientific judgment and human preferences (Ruhl et al. 2009; Quétier \& Lavorel 2011). Aggregation rules are based on assumptions about the substitutability of functions at site and landscape scales (Langhans et al. 2014), and these assumptions can profoundly affect the evolution of functions on restored landscapes. Weighted-average rules used to aggregate site functions in offset schemes (Rayment 2014), such as the habitat-hectare approach used in Victoria's (Australia) Native Vegetation Offset Program, have been criticized because they are based on the assumption that ecosystem functions are substitutable; that is, one function can be substituted for another to determine the aggregated score (McCarthy et al. 2004). The challenge of combining diverse functions such as hydrology, water purification, and biodiversity is even more pronounced. There is little evidence to support a particular aggregation approach; researchers report both cobenefits and trade-offs among functions (Hansson et al. 2005; Jessop et al. 2015). Consequently, offsets may cause unanticipated losses of ecosystem functions at a landscape scale and convert multifunctional landscapes that are more likely to be resilient (Suding et al. 2015) into simpler ones specializing in a few functions or one function (de Groot et al. 2010).

We simulated the effect of aggregation rules on ecosystem functions for wetland offsets in the Beaverhill watershed of Alberta (Canada), where historical loss of wetlands is substantial and compensation policies targeting ecosystem functions have recently been put in place. Wetlands are particularly suited to this analysis because they provide multiple functions in different proportions. We compared changes in hydrology $(\mathrm{H})$, water purification (WP), and biodiversity (B) functions between affected and restored wetlands under different aggregation rules that encompassed a range of assumptions about the substitutability of ecosystem functions. We compared the distribution of ecosystem functions between affected and restored wetlands at both wetland and landscape scales. Although focused on wetlands, our results contribute to a better understanding of the interplay between offset equivalence rules and ecosystem functions for all ecosystems. We considered the implications of aggregating rules for landscape resilience and then identified 5 criteria for designing aggregation rules for offset programs.

\section{Methods}

\section{Study Site}

The Beaverhill watershed is in the Prairie Pothole Region of central Alberta, Canada (Fig. 1). The watershed contains the Cooking Lake Moraine, which was recently named a UN Educational, Scientific and Cultural Organization Biosphere Reserve (UNESCO 2016), and Beaverhill Lake, a wetland of international significance for its

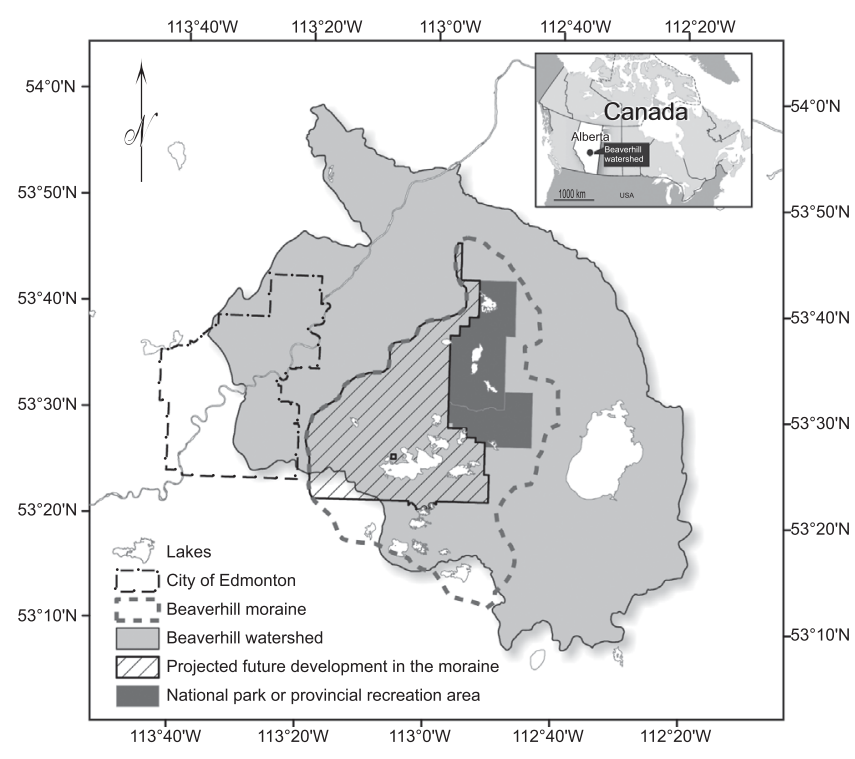

Figure 1. Beaverbill watershed showing the projected expansion of rural residential development (cross-hatching) based on Strathcona County's (2006) Municipal Development Plan Bylaw 1-2007.

breeding and staging of migratory water- and shorebirds (Ramsar Convention 1971). Wetland losses in the watershed have been large (Serran \& Creed 2016). Urban expansion poses a risk to remaining wetlands because projected population growth rates in Edmonton are 1.3\%/year until 2041 (Government of Alberta [GOA] 2007). In 2013, the GOA introduced a wetland policy with a stated goal to maintain ecosystem functions through avoidance and minimization of wetland drainage and compensation for unavoidable wetland losses (GOA 2013).

\section{Function Scores}

The GOA's Wetland Policy (2013) defined ecosystem functions for $\mathrm{H}, \mathrm{WP}$, and $\mathrm{B}$ and states that these functions should be maintained on the landscape (GOA 2013). $E x$ isting, affected, restorable, and restored wetlands are defined in Supporting Information. Existing wetlands were identified from the Canadian Wetland Inventory (Ducks Unlimited Canada 2016) and were mapped using aerial photography (minimum mapping unit of $0.02 \mathrm{ha}$ ) or Satellite Probatoire d'Observation de la Terre (SPOT) imagery (minimum mapping unit of $0.04 \mathrm{ha}$ ). Existing wetlands were classified according to the Canadian Wetland Classification system classes of open water, marsh, swamp, bog, and fen (National Wetlands Working Group 1997). Restorable wetlands were existing wetlands with a fabricated drainage ditch intersecting their boundaries (drainage ditches mapped using a 3 m LiDAR bare earth 
digital elevation model and the digital terrain analysis methods developed by Waz and Creed [2017]).

Existing and restorable wetlands were assessed and provided with a function score following the automated method developed by Creed et al. (2018). The GOA developed 2 ecosystem-function assessment systems: a remote tool (used here) and an on-the-ground tool (used when wetland development occurs). For the remote tool, 73 indicators were derived from remote sensing or GIS (geographic information system) data layers provided by the GOA to assess ecosystem function for each wetland. Many indicators for computing functions were based on landscape characteristics (e.g., soil texture), whereas other indicators were based on wetland characteristics (e.g., percentage of vegetated wetland area). It was impossible to assign values for wetland characteristic indicators to restorable wetlands because they did not yet exist. Therefore, we calculated the average value of the indicator for all existing wetlands and assigned this value to the restorable wetlands. Indicators were normalized from 0 to 1 and combined to establish subfunction scores based on models for which expert opinion was used that was based on peer-reviewed literature. The highest subfunction score for a given function was taken as the function score for that wetland (Fig. 2). Function scores were then aggregated into an overall wetland score with different aggregation rules. We calculated indicators, subfunctions, and functions for existing wetlands $(n=85,584)$ and for restorable wetlands $(n=6,004)$. We assigned function scores to restorable wetlands based on the assumption that functions would be fully restored with no time lag. This is a simplifying assumption that is consistent with how function scores are often assigned in practice; however, mitigation ratios are also often applied to account for uncertainty and time lags in restoration benefits (e.g., Weber et al. 2015).

\section{Rules for Aggregating Function Scores to Wetland Scores}

We explored 6 aggregation rules for calculating wetland scores (WS). The first 4 rules were based on weighted averages ( $W S=\sum_{i=1}^{n} w_{i} F S_{i}$, where $\mathrm{n}(=3)$ is the number of functions, $w_{i}$ are weights [summing to 1] and $F S_{i}$ are the normalized function scores). We compared an equalweight aggregation rule $\left(w_{H}=w_{\mathrm{WP}}=w_{B}=1 / 3\right)$ with priority weight rules for each of the functions: $\mathrm{H}$ priority, WP priority, and B priority. Under priority rules, the prioritized function received a weight of 0.9 , and the other 2 functions received weights of 0.05 . For example, for the $\mathrm{H}$ priority rule, a weight of 0.9 was assigned to $\mathrm{H}$ and a weight of 0.05 was assigned to both WP and $\mathrm{B}$. Weights were chosen to highlight the sensitivity of outcomes to rules that put a very high weight on one function, perhaps due to public preferences or legal requirements, whereas nonzero weights for the other functions were maintained. We also tested 2 rules, minimum and maxi- mum, that focus on the extreme values of the function scores expressed in affected wetlands. The minimum rule assigned a wetland score equal to the lowest function score: $\mathrm{WS}=\min (\mathrm{H}, \mathrm{WP}, \mathrm{B})$. The maximum rule assigned a wetland score equal to the highest function score: $\mathrm{WS}=\max (\mathrm{H}, \mathrm{WP}, \mathrm{B})$.

\section{Effect of Aggregation Rules on Wetland Scores}

We used Kendall's rank correlation coefficient (Kendall 1938) (i.e., Kendall's tau $[\tau]$ ) to compare the pairwise ranking of individual wetlands against individual functions as well as under different aggregation rules. Its range is -1 to 1 , where a value of -1 indicates complete discordance in the pairwise ranking of wetlands and a value of +1 indicates complete concordance.

\section{Equivalence between Affected and Restored Wetlands}

We applied an algorithm (hereafter the affect-and-offset algorithm) to the set of existing wetlands within the area zoned for residential expansion within the study area (Fig. 1). The algorithm is described in detail in Supporting Information. We randomly selected 150 wetlands to be affected within the area zoned for residential expansion; each wetland in the area had an equal probability of being affected. The number of wetlands affected approximated losses reported by Clare and Creed (2014), who found that 242 wetlands were lost in the Beaverhill watershed over the 10-year period from 1999 to 2009. Approximately $60 \%$ (145) of lost wetlands came from urban, periurban, and mixed agriculture land uses represented within the area zoned for residential expansion (Fig. 1).

The equivalence between affected and restored wetlands required the area-weighted wetland score of the restored wetlands to equal or exceed the area-weighted wetland score of the affected wetlands. The spatial configuration of wetlands was not considered in this equivalence requirement. For each of the 150 affected wetlands, we searched the set of restorable wetlands for wetlands that would qualify as offsets (i.e., restorable wetlands that satisfied the equivalence requirement): $\mathrm{WS}_{\mathrm{AFF}} \times A_{\mathrm{AFF}} \leq$ $\sum_{i=1}^{s} \mathrm{WS}_{\mathrm{OFF}_{i}} \times A_{\mathrm{OFF}_{i}}$, where $\mathrm{WS}_{\mathrm{AFF}}, \mathrm{WS}_{\mathrm{OFF}}, A_{\mathrm{AFF}}$, and $A_{\mathrm{OFF}}$ represent the scores and areas of affected and offset wetlands, respectively, and $s$ represents the number of wetlands used for compensation. The restored wetlands were selected from the set of restorable wetlands based on the criterion of minimizing the total area restored subject to satisfying the equivalence requirement. The minimum area criterion is analogous to minimizing costs if wetland restoration costs were homogeneous. We then applied the affect-and-offset algorithm to each of the affected wetlands. We repeated the affect-andoffset algorithm 100 times for each aggregation rule, each time removing the same 150 wetlands in a different random order to control for potential bias caused by the 


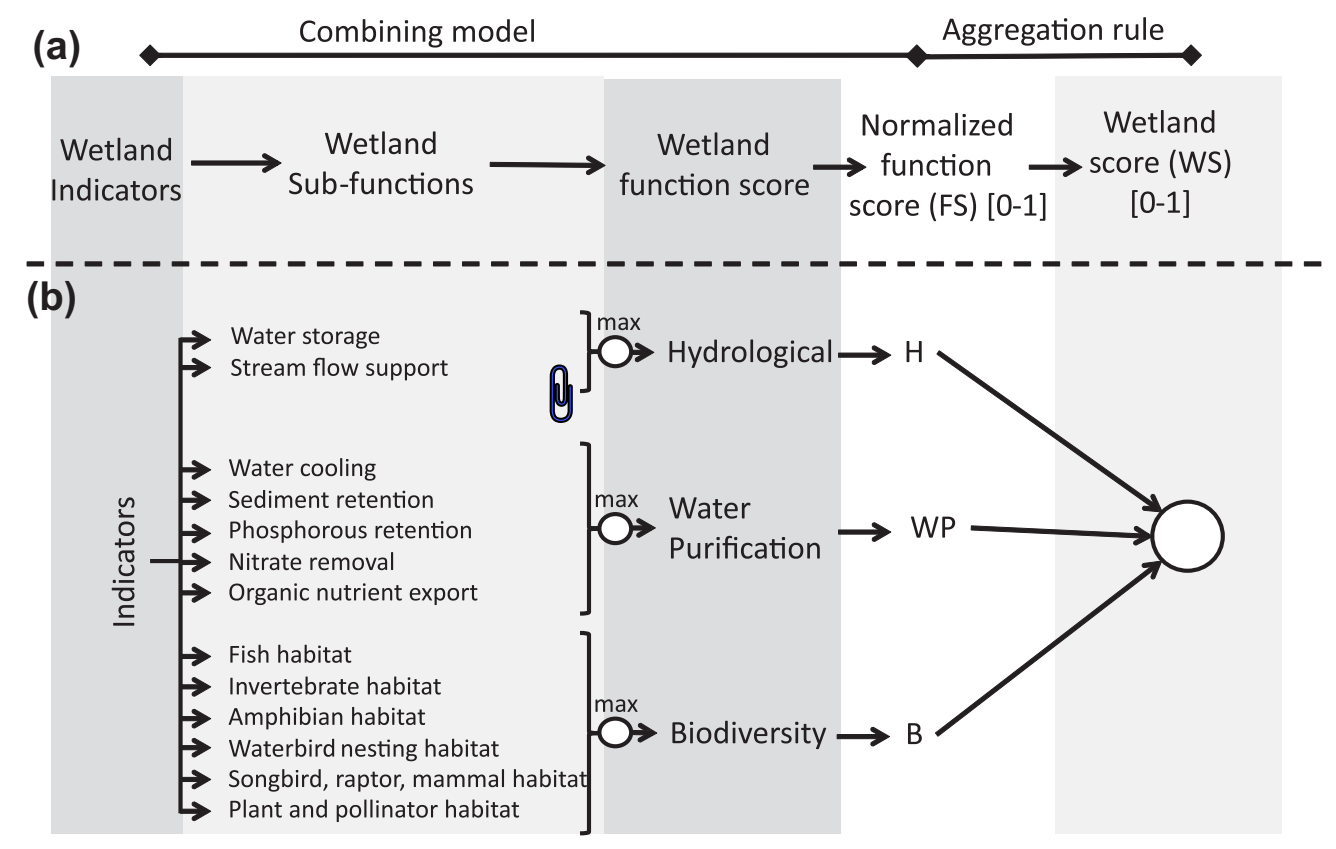

Figure 2. (a) Sequence of steps for calculating scores related to bydrology, water purification, and biodiversity functions and the overall wetland scores. Steps include combining indicators into subfunctions through which the maximum subfunction score defines the function score, normalizing function scores, and then aggregating normalized function scores under different aggregation rules to obtain a wetland score. (b) Lists of wetland subfunctions, functions (hydrology, water purification, and biodiversity), and normalized functions ( $H, W P$, and $B)$.

order in which wetlands were affected. We compared the results of the 100 simulations and found that $95 \%$ of the restored wetlands were the same for all simulations, suggesting ordering bias did not significantly affect the results.

We averaged the restored function scores over the 100 simulations to obtain distribution parameters for restored functions, which we compared with the distribution of affected functions. We used a 2-sample $t$ test to test the significance of pairwise differences in the averages of function scores, and we used a 2-sample KolmogorovSmirnov (KS) test to compare the difference in frequency distributions between existing and restorable wetlands and affected and restored wetland function scores under different aggregation rules. For each function, we compared the average score of restored wetlands to the maximal achievable score (e.g., White $\&$ Fennessy 2005), defined as the average function score for the top 150 restorable wetlands, to evaluate whether we restored wetlands with the highest function scores.

\section{Mono- versus Multifunctionality of Affected and Restored Wetlands}

To compare the quality and multifunctionality of existing, restorable, and restored wetlands, we plotted the mean function score (MFS) (mean of the 3 normalized func- tions) for each wetland against a Gini coefficient describing the equality in the function scores within wetlands. The Gini coefficient is calculated as (Dorfman 1979):

$$
G=\frac{\sum_{i=1}^{n} \sum_{j=1}^{n}\left|x_{i}-x_{j}\right|}{2 n \sum_{i=1}^{n} x_{i}}
$$

where $n(=3)$ is the number of functions and $x_{i}$ and $x_{j}$ represent the individual function scores at each wetland. For individual wetlands, a Gini coefficient close to 0 indicated a wetland was multifunctional (i.e., functions were in relatively more equal proportions), whereas a Gini coefficient close to 1 indicated greater inequality in the function score (i.e., 1 function dominated). A high MFS together with a low Gini coefficient indicated a high-quality multifunctional wetland. We also defined and calculated a landscape Gini coefficient to measure the diversity of functions provided by wetlands on the landscape by summing the function scores for each function over the set of wetlands and calculating the Gini coefficient for the summed function scores. A landscape Gini coefficient close to 0 indicated the functions were equally distributed in the landscape, whereas a landscape Gini coefficient close to 1 indicated the functions were unequally distributed. 


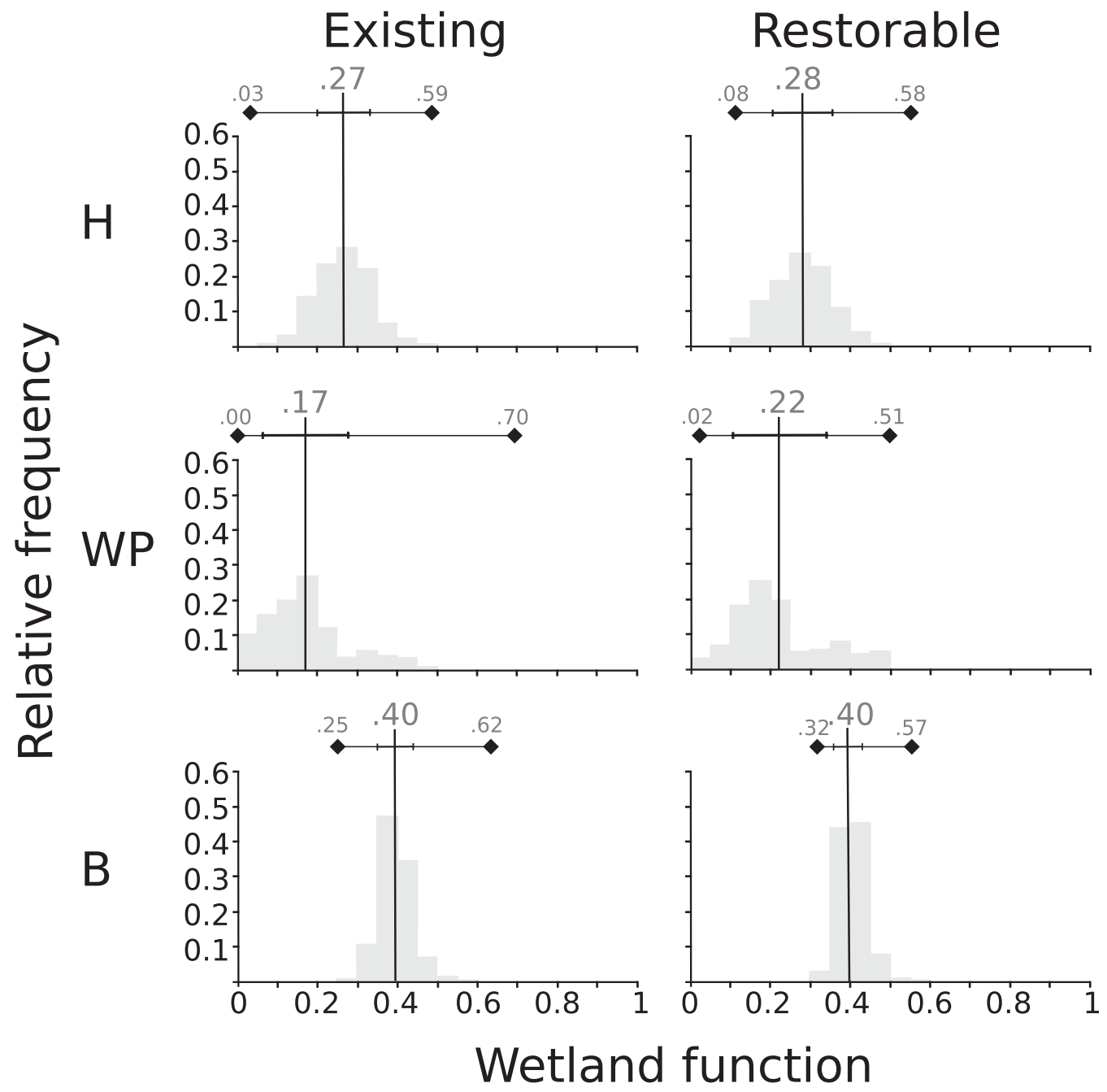

Figure 3. Relative frequency distribution of hydrology (H), water purification (WP), and biodiversity (B) functions for existing and restorable wetlands in the Beaverhill watershed (vertical lines, averages of the distribution; light gray borizontal lines, distribution range; diamonds at far left and right of horizontal lines, minimum and maximum values of the distribution, respectively; central black horizontal line delimited by vertical lines, standard deviation of the distribution).

\section{Results}

\section{Function Scores}

The KS tests $(\alpha=0.05)$ showed significant differences in the distributions of function scores between existing and restorable wetlands (Fig. 3; Supporting Information). Although differences in averages were small, $t$ tests (Supporting Information) confirmed that the average scores of all functions were significantly $(p<0.001)$ higher in restorable than in existing wetlands. This indicated that, historically, higher functioning wetlands were affected and therefore available for restoration. The difference was significant for all functions, including B, which had an average score of 0.40 for both existing and affected wetlands. However, variance for B was higher for existing than restorable wetlands, indicating that the potential for improving scores for B through restoration was lower than for other functions.

\section{Effects of Aggregation on Prioritizing Wetlands}

Based on the critical value of $\tau$, all pairwise combinations of wetland rankings under individual function scores and aggregation rules were either significantly concordant or discordant; higher positive or negative values for $\tau$ indicated more concordance or discordance, respectively, between the rankings (Supporting Information). With $\tau=0.49, \mathrm{H}$ and WP functions showed concordance, indicating many pairs of wetlands had the same relative ranking for both functions. The $\mathrm{B}$ function was less concordant with the WP function $(\tau=0.04)$ and discordant with the $\mathrm{H}$ function $(\tau=-0.14)$. The maximum and 
equal-weight rules were the most concordant with $B$ and the B priority rule. Overall, the WP priority rule showed the most concordance with the other aggregation rules and the B priority rule showed the least concordance.

\section{Effect of Aggregation on the Distribution of Functions in Restored Wetlands}

The KS test showed that each aggregation scheme significantly changed the distribution of each function (Supporting Information). Average function scores shifted significantly for almost all functions (the KS test is based on all moments of the distribution); however, the averages of the $\mathrm{H}$ and WP functions did not shift under the $\mathrm{B}$ priority rule, and the average of the $\mathrm{B}$ function did not shift under the equal weight and $\mathrm{H}$ priority rules.

The H, WP, and B functions improved (i.e., the frequency distribution shifted to the right [Fig. 4]) under rules prioritizing those same functions. The $\mathrm{H}$ and $\mathrm{WP}$ functions increased under both the $\mathrm{H}$ and WP priority rules, reflecting the concordance between these functions (Supporting Information), whereas the B function decreased. Similarly, the $H$ and WP decreased under the $\mathrm{B}$ priority rule, reflecting B function's lower concordance with $\mathrm{H}$ and WP functions (Supporting Information). There were no trade-offs between functions under equal-weight, minimum, or maximum rules, each of which led to improvements in all functions. For all rules, the average function scores for restored wetlands were lower than the maximum achievable function score. Furthermore, the variance of the restored B function was always equal or lower than the other 2 functions, as reflected by the low variance of the restorable function in the landscape. For the 3 functions, none of the aggregation rules led to restoration of the maximum restorable function.

\section{Quality and Multifunctionality of Affected and Restored Wetlands}

The average function scores showed the quality and the Gini coefficients showed the multifunctionality of restored wetlands under different aggregation rules (Fig. 5). All aggregation rules resulted in an improvement in the average function score (Supporting Information). The equal weight and maximum rules resulted in the highest average function score in restored wetlands (average MFS equal to 0.55 and 0.52 , respectively), whereas the B priority and minimum rules resulted in the lowest (average MFS equal to 0.43 and 0.49 , respectively).

The average Gini coefficient (Supporting Information) indicated that the relative equality of function scores within wetlands was higher for affected than restorable wetlands. The $B$ priority rule resulted in the greatest inequality in function scores (average Gini coefficient = 0.21 ) for restored wetlands due to lack of concordance with $\mathrm{H}$ and WP functions. The maximum rule resulted in high but not the greatest inequality in function scores for restored wetlands (average Gini coefficient $=0.18$ ). The other aggregation rules reduced the inequality of functions relative to the average restorable wetland, in particular equal-weight and minimum rules (average Gini coefficient equal to 0.12 and to 0.10 ).

The landscape Gini coefficient (Supporting Information) revealed an interesting shift in the equality of functions between existing and restorable wetlands; the latter had greater equality at the landscape scale. This meant that inequalities present in individual restorable wetlands were averaged out at the landscape scale. At the landscape scale, the $\mathrm{B}$ priority rule resulted in the greatest inequality among functions (landscape Gini coefficient = 0.20 ), whereas the minimum rule resulted in the greatest equality among functions (landscape Gini coefficient = 0.04). The maximum rule resulted in low inequality (although not as much as the minimum rule) among functions at the landscape scale (landscape Gini coefficient = 0.07), despite having the greatest inequality at the site scale.

\section{Discussion}

With numerous countries embracing offsets as a core conservation strategy, it is important to clarify no-net-loss objectives for scaled-up programs at landscape scales. Aggregation rules implicitly embed priorities for different ecosystem functions and therefore jeopardize no-net-loss objectives (Maron et al. 2016). There can be unintended consequences because changes in functions at the landscape scale may not reflect weights in the aggregation rules. We therefore recommend nesting no-net-loss objectives and aggregation rules within a landscape prescription that addresses desired landscape heterogeneity and complexity in restoration planning (Hessburg et al. 2015). We identified 5 criteria-substitutability, cobenefits and trade-offs, constraints on restoration opportunities, heterogeneity, and the precautionary principle (Table 1)-that should be considered in the design of aggregation rules to operationalize no-net-loss objectives within a landscape prescription. These criteria provide operational guidance for implementing internationally accepted standards for offsetting, for example those set out in the Business and Biodiversity Offsets Programme standard (BBOP 2012), particularly criteria relevant at the landscape context (where offsets should be designed and implemented in a landscape context to achieve the expected measurable conservation outcomes) and for no net loss (where offsets should be designed to achieve measurable conservation outcomes that can reasonably be expected to result in no net loss and preferably a net gain of biodiversity) (BBOP 2012). 


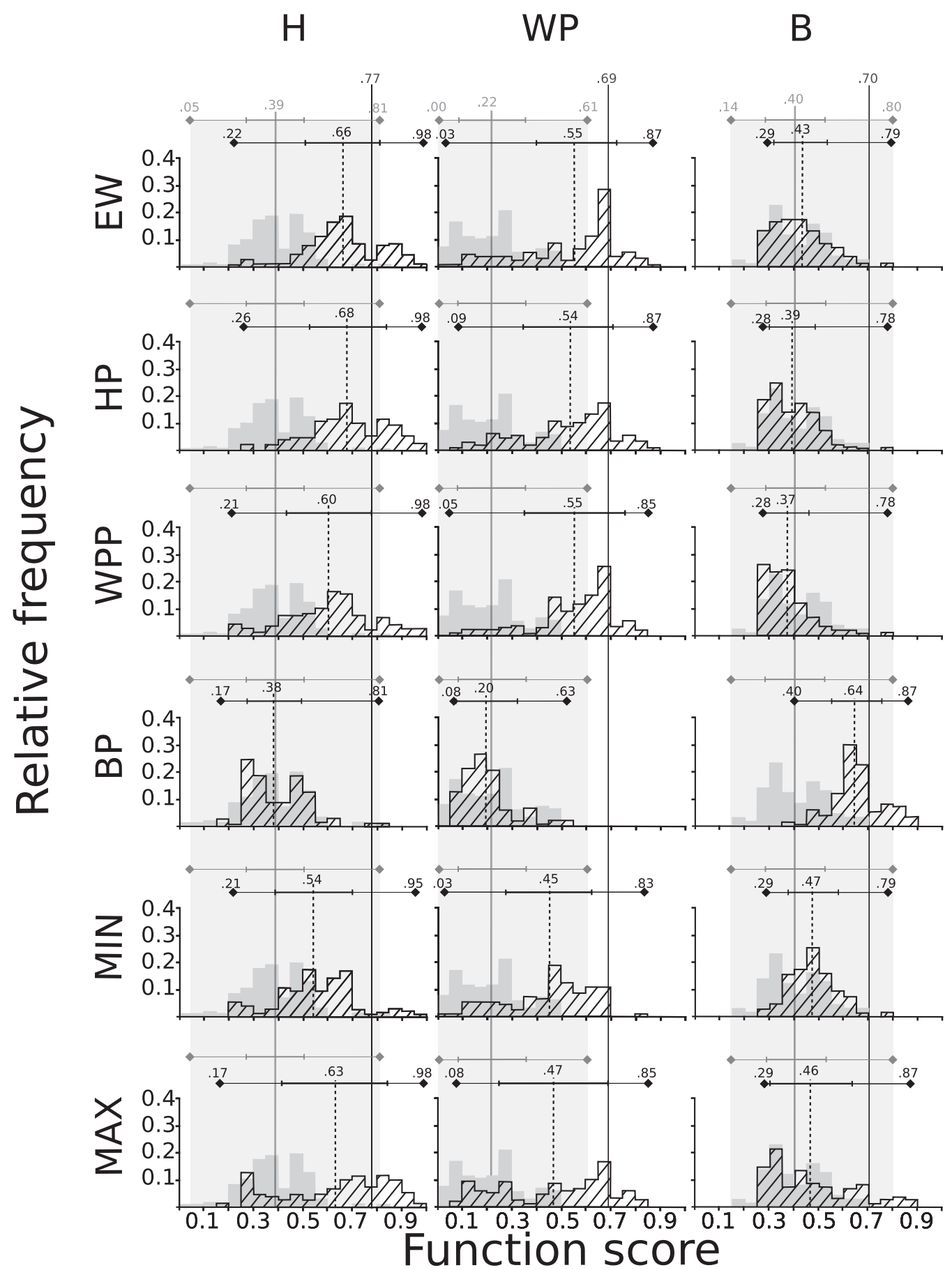

Figure 4. Relative frequency distribution (histograms) of function scores for affected (gray shading) and restored (diagonal lines) wetlands based on Monte Carlo simulations of the affect-and-offset algorithm (vertical black dashed line, average restored function; horizontal black line delimited by vertical lines, SD of the function within the restored wetlands; horizontal black line delimited by diamonds, range of the function within the restored wetlands). Rows of bar plots represent the different aggregation schemes (EW, equal weight; HP, bydrology priority; WPP, water purification priority; BP, biodiversity priority; MIN, minimum weight; MAX, maximum weight), and the 3 columns represent the 3 wetland functions ( $H$, bydrology; WP, water purification; $B$, biodiversity). The columns elements: vertical gray line, average function within affected wetlands; gray horizontal line delimited by diamonds and gray-shaded area, range of the function of the affected wetlands; gray horizontal lines delimited by vertical bars, $S D$ of the function within the affected wetlands; vertical black line, average function of the best 150 restorable wetlands according to the function considered. 


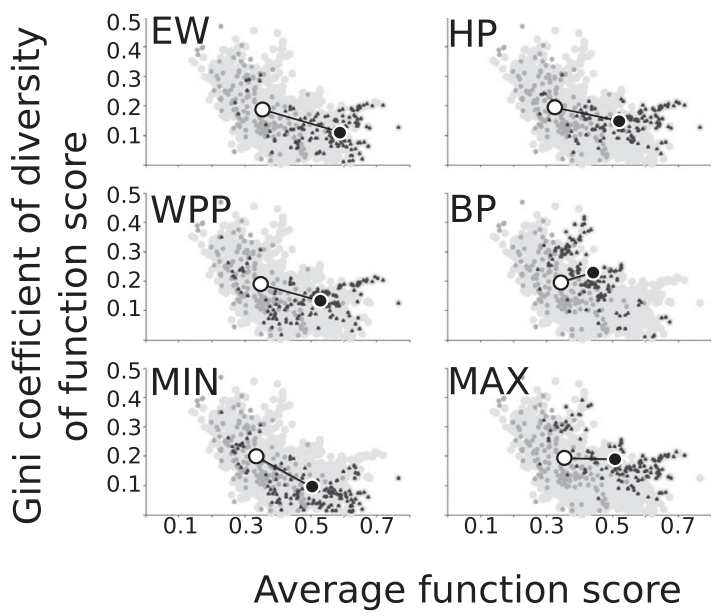

Figure 5. Average function score representing quality versus Gini coefficient representing the diversity of functions within wetlands for restorable (light gray dots), affected (gray dots), and restored (dark gray dots) wetlands (Supporting Information) under bydrology priority (HP), water purification priority (WPP), biodiversity priority (BP), equal-weight (EW), minimum (MIN), and maximum (MAX) aggregation rules (large dots, average of the points for the affected [white dot] and restored [black dot] wetlands; connection between large dots, shift in multifunctionality of the wetlands in the landscape).

\section{Substitutability}

Although weights may seem intuitive to decision makers as a way to address people's preferences for certain functions, we found that functions did not change in proportion to the weights assigned. In particular, equal weighting, which suggests balance among functions, did not result in equal increase of functions in restored landscapes. The equal weight, priority weight, and maximum rules were based on the assumption that functions are perfect substitutes (albeit at different ratios). This can be contrasted with the minimum rule, which is based on the assumption of complementarity rather than substitutability between functions. The minimum rule restored functions in proportion to a minimum threshold, ensuring that each function in restored wetlands scores at least as high as the worst function of the affected wetland. Although priority weighting schemes gave preference to certain functions in selecting restoration sites, the final restoration site was determined by the total score, and not the value of the prioritized function. The maximum rule allowed substitution between functions but focused on individual high-value functions at the affected and restored sites, ensuring that high-quality functional losses were substituted with high-quality functional gains. The modification of other functions under the priority weight and maximum rules depended on cobenefits and tradeoffs among functions.

\section{Cobenefits and Trade-offs}

Concordance and discordance between functions may result in cobenefits and trade-offs leading to unintended negative consequences for some functions on the landscape. These consequences were particularly pronounced under priority weight rules. We showed how Kendall's rank correlation coefficient could be used to screen different aggregation rules to minimize risks of unanticipated negative consequences due to concordance, discordance, or independence among

Table 1. Criteria for operationalizing a landscape approach to no net loss of ecosystem functions.

\begin{tabular}{|c|c|}
\hline Criteria & Operationalization \\
\hline $\begin{array}{l}\text { Substitutability: Ensure allowable thresholds of } \\
\text { substitution between ecosystem functions and } \\
\text { services are explicitly incorporated in } \\
\text { no-net-loss objectives. }\end{array}$ & $\begin{array}{l}\text { Define no-net-loss goals in terms of functions and their distributions. } \\
\text { Specify acceptable thresholds for substitution between functions at } \\
\text { different scales in no-net-loss objectives. } \\
\text { Test the aggregation scheme to ensure that the distribution of restored } \\
\text { functions on the landscape reflects acceptable thresholds. }\end{array}$ \\
\hline $\begin{array}{l}\text { Cobenefits and trade-offs: Consider cobenefits } \\
\text { and trade-offs between functions to minimize } \\
\text { unanticipated consequences. }\end{array}$ & $\begin{array}{l}\text { Use Kendall's rank correlation coefficient or a similar correlation statistic to } \\
\text { assess the concordance, discordance, and independence among } \\
\text { functions. } \\
\text { Assess cobenefits and trade-offs between functions to ensure that } \\
\text { aggregation rules enhance cobenefits where possible and minimize } \\
\text { negative unanticipated consequences from trade-offs among functions. }\end{array}$ \\
\hline $\begin{array}{l}\text { Constraints: Identify constraints to restoring } \\
\text { functions on the landscape. }\end{array}$ & $\begin{array}{l}\text { Qualitatively or quantitatively assess maximum restorable ecosystem } \\
\text { functions for the set of restorable sites. } \\
\text { Identify effects of economic and policy constraints on restoration potential } \\
\text { for ecosystem functions. }\end{array}$ \\
\hline Take a precautionary approach. & $\begin{array}{l}\text { Use a precautionary approach to offsetting that maintains a full suite of } \\
\text { ecosystem functions at different scales. }\end{array}$ \\
\hline
\end{tabular}


different functions. We expect cobenefits and trade-offs to be significant factors determining the distribution of functions in restored landscapes. For example, the tradeoffs identified between WP and B functions in our landscape have been identified in other studies (Hansson et al. 2005; Barnett et al. 2016). Barnett et al. (2016) recommend spatially quantifying ecosystem trade-offs when optimizing restoration benefits.

\section{Constraints on Restoration Opportunities}

Physical constraints may limit opportunities to improve some ecosystem functions. For example, the high value and tight distribution for the B function score in both affected and restorable sites limited the ability to improve this function relative to other functions under weighted-average rules, even if it is given a priority weight. Economic constraints may also limit opportunities to achieve maximum restoration potential. In selecting restoration sites, the minimum-area criterion resulted in bypassing the largest and highest scoring sites because they were more costly. This raises an important policy consideration because evidence suggests there are significant economies of scale for functions such as biodiversity (Moreno-Mateos et al. 2012). Without additional minimum-area constraints or mitigation ratios to provide stronger incentives to restore large high-quality wetlands, economies of scale may not be realized.

\section{Heterogeneity}

Spatial heterogeneity in ecosystem functions is fundamental to landscape resilience (Pickett \& Cadenasso 1995). We used the Gini coefficient combined with the average wetland score to explore implications for heterogeneity at different scales and potential implications for resilience. The maximum rule resulted in high functional inequality at the site scale and high multifunctionality at the landscape scale, whereas the minimum rule resulted in high multifunctionality at both scales. The maximum rule targeted the highest function score on each wetland, but because it did not discriminate in terms of function, it did not introduce inequality at the landscape scale. Thus, the minimum and maximum rules achieved landscape multifunctionality through different pathways, with the minimum rule restoring multifunctional wetlands and the maximum rule restoring high value, specialized function wetlands.

\section{Precautionary Principle}

Building on the heterogeneity criterion, ecosystems may not be reduced to the sum of their parts, and high levels of uncertainty about complex landscape dynamics requires a precautionary approach to offsetting that main- tains a full suite of ecosystem function at different scales (Moreno-Mateos et al. 2015). Heterogeneity in function scores within and between restored wetlands may be just as important as the function scores in determining landscape resilience (Little \& Grafton 2015). With an emphasis on multifunctionality at multiple scales, the precautionary principle is best operationalized through the minimum and maximum rules; the minimum rule was the only rule that achieved multifunctionality at both scales.

Although our results are specific to the particular expression of wetland functions in our study area, the 5 criteria may be used to guide the operationalization of offset schemes when aggregating multiple functions and services. The aggregation rules we considered represent various endpoints, including 2 extreme value functions as well as balanced and unbalanced weighted average schemes. These schemes were selected to be representative of particular classes of aggregation rules to highlight underlying assumptions and consequences for each class. An unbalanced rule could represent a situation where stakeholders are particularly concerned about increasing one function on the landscape. We did not explicitly consider uncertainty in the underlying distributions of functions; further analysis would be required to determine how the distribution of function scores on the landscape would shift under different aggregation rules if the underlying distributions were asymmetric or if there was systematic bias in the error terms. If variance in the underlying distributions was correlated between functions, this could increase the cobenefits and trade-offs between functions.

The aggregation schemes themselves are simply accounting rules and do not address, per se, other ecosystem components that must be considered in restoration, including time lags to benefits and uncertainty in restoration success. Because time lags were not accounted for, the aggregation schemes could only be used to evaluate equivalence over space but not across time. Time lags may be dealt with through multipliers to reflect discount rates for losses of current values and restoration uncertainty. These multipliers, which account for risk and time lags, should also be applied according to the same landscape considerations as other factors of equivalence. Further analysis is required to understand how aggregation rules might interact with uncertainty and lead to a preference for one rule over another in the context of restoration risk, particularly when there are cobenefits and trade-offs between functions.

Our criteria for designing aggregation rules are suitable for offset policies that are applied on a case-bycase basis as well as programs that use a market-based mechanism (e.g., BushBroker in Victoria and biobanking in New South Wales, Australia, and wetland and species banking in the United States). Offset programs that do 
not explicitly match losses and gains fall outside the definition of no-net-loss programs; nonetheless, no net loss is still a valuable benchmark for evaluating program performance. These include programs that use planning tools to prioritize restoration to sites of greatest ecological value such as Columbia's offset program (Mandle et al. 2016) and the program proposed for oil sands development in Alberta Canada (Habib et al. 2013). In all cases, agencies should incorporate the criteria and constraints identified in this analysis in assessing the scaled up implications of the offset program and include indicators of site complexity and landscape heterogeneity in evaluating restoration priorities and offset outcomes.

Finally, our findings point to the need to reconsider the idea of no net loss and the scale at which it is applied. No-net-loss policies do not apply to ecosystems but rather to values reflected in offset metrics (Moreno-Mateos et al. 2015). Once we move beyond no net loss for individual functions such as biodiversity, implementing the concept of no net loss becomes challenging and can only be considered within the context of landscape design to address landscape characteristics, such as heterogeneity and connectivity (e.g., Bruggeman et al. 2009) that are critical attributes for resilience.

Offset and compensatory mitigation programs use aggregated indices to equate function losses and gains on degraded and offset sites. Aggregation rules should be chosen with careful consideration of cobenefits and trade-offs among functions and of the physical and economic constraints imposed by the functional potential of restorable sites. Positive (and negative) correlations between functions can contribute to unanticipated losses of functions in restored landscapes. For example, weightedaverage rules tend to unbundle the multiple ecosystem functions expressed in existing wetlands and redistribute them independently in restored wetlands, which can contribute to monofunctional landscapes. Precautionary rules that require proportionality in gains or the replacement of high-value functions with equally highvalue functions lead to more multifunctional landscapes but in different ways, and there are trade-offs between site quality and site heterogeneity. Resilience of landscapes is important, particularly in the face of uncertainty associated with climate change; therefore, offset policies based on weighted-average aggregation rules should be reconsidered. More research is required on desired landscape prescriptions that could be tied to offset rules.

\section{Acknowledgments}

This research was funded by the NSERC Canadian Network for Aquatic Ecosystem Services (http://www.cnaes. ca/) and Alberta Innovates Technology Futures (http:// www.albertatechfutures.ca/).

\section{Supporting Information}

Definitions and the affect-and-offset algorithm (Appendix S1) and results of statistical tests (Appendix S2) are available online. The authors are solely responsible for the content and functionality of these materials. Queries (other than absence of the material) should be directed to the corresponding author.

\section{Literature Cited}

Barnett A, Fargione J, Smith MP. 2016. Mapping trade-offs in ecosystem services from reforestation in the Mississippi Alluvial Valley. BioScience 66:223-237.

Bruggeman D, Jones M, Scribner KT, Frank L. 2009. Relating tradable credits for biodiversity to sustainability criteria in a dynamic landscape. Landscape Ecology 24:775-790.

Bull JW, Gordon A, Watson JEM, Maron M. 2016. Seeking convergence on the key concepts in "no net loss" policy. Journal of Applied Ecology 53:1686-1693.

Business and Biodiversity Offsets Programme (BBOP). 2012. Standard on biodiversity offsets. BBOP, Washington, D.C. Available from http:// bbop.forest-trends.org/guidelines/Standard.pdf (accessed October 2017).

Clare S, Creed IF. 2014. Tracking wetland loss to improve evidencebased wetland policy learning and decision making. Wetlands Ecology and Management 22:235-245.

Creed IF, Aldred DA, Serran JN, Accatino F. 2018. Maintaining the portfolio of wetland functions on landscapes: a rapid evaluation tool for estimating wetland functions and values. In Dorney J, Savage R, Tiner R, Adamus P, editors. Wetland and stream rapid assessments: development, validation, and application. Elsevier, Cambridge, Massachusetts.

de Groot RS, Alkemade R, Braat L, Hein L, Willemen L. 2010. Challenges in integrating the concept of ecosystem services and values in landscape planning, management and decision making. Ecological Complexity 7:260-272.

Dorfman R. 1979. A formula for the Gini coefficient. Review of Economics and Statistics 61:146-149.

Ducks Unlimited Canada. 2016. Canada wetland inventory data model. Ducks Unlimited Canada, Stonewall, Manitoba. Available from http://www.ducks.ca/assets/2016/07/CWIDMv7_01.pdf (accessed September 2016).

Government of Alberta (GOA). 2007. Working together: report of the capital region integrated growth management plan project team. Government of Alberta, Edmonton, Alberta. Available from http:// www.assembly.ab.ca/lao/library/egovdocs/2007/alz/164041.pdf (accessed January 2017).

Government of Alberta (GOA). 2013. Alberta Wetland Policy. Government of Alberta, Edmonton, Alberta, Canada. Available from http:// aep.alberta.ca/water/programs-and-services/wetlands/documents/ AlbertaWetlandPolicy-Sep2013.pdf (accessed September 2016).

Habib TJ, Farr DR, Schneider RR, Boutin S. 2013. Economic and ecological outcomes of flexible biodiversity offset systems. Conservation Biology 27:1313-1323.

Hansson L-A, Brönmark C, Nilsson PA, Åbjörnsson K. 2005. Conflicting demands on wetland ecosystem services: Nutrient retention, biodiversity or both? Freshwater Biology 50:705-714.

Hessburg PF, et al. 2015. Restoring fire-prone inland pacific landscapes: seven core principles. Landscape Ecology 30: 1805-1835.

ICMM IUCN (International Council on Mining and Metals International Union for Conservation of Nature). 2013. Independent report on biodiversity offsets. The Biodiversity Consultancy, 
London. Available from https://www.icmm.com/website/ publications/pdfs/biodiversity/biodiversity-offsets (accessed October 2017).

Jacob C, Vaissiere A-C, Bas A, Calvet C. 2016. Investigating the inclusion of ecosystem services in biodiversity offsetting. Ecosystem Services 21:92-102.

Jessop J, Spyreas G, Pociask GE, Benson TJ, Ward MP, Kent AD, Matthews JW. 2015. Tradeoffs among ecosystem services in restored wetlands. Biological Conservation 191:341-348.

Kendall MG. 1938. A new measure of rank correlation. Biometrika 30:81-93.

Langhans SD, Reichert P, Schuwirth N. 2014. The method matters: a guide for indicator aggregation in ecological assessments. Ecological Indicators 45:494-507.

Little LR, Grafton RQ. 2015. Environmental offsets, resilience and costeffective conservation. Royal Society Open Science 2:140521.

Mandle L, Douglas J, Lozano JS, Sharp RP, Vogl AL, Denu D, Walschburger T, Tallis H. 2016. OPAL: an open-source software tool for integrating biodiversity and ecosystem services into impact assessment and mitigation decisions. Environmental Modelling \& Software 84:121-133.

Maron M, et al. 2016. Taming a wicked problem: resolving controversies in biodiversity offsetting. Bioscience 66:489-498. https://doi.org/10.1093/biosci/biw038.

McCarthy MA, et al. 2004. The habitat hectares approach to vegetation assessment: an evaluation and suggestions for improvement. Ecological Management \& Restoration 5:24-27.

Metzger MJ, Rounsevell MDA, Acosta-Michlik L, Leemans R, Schröter D. 2006. The vulnerability of ecosystem services to land use change. Agriculture, Ecosystems and Environment 114:69-85.

Moreno-Mateos D, Power ME, Comín FA, Yockteng R. 2012. Structural and functional loss in restored wetland ecosystems. PLOS Biology 10 (e1001247). https://doi.org/10.1371/journal.pbio. 1001247.

Moreno-Mateos D, Maris V, Béchet A, Curran M. 2015. The true loss caused by biodiversity offsets. Biological Conservation 192: 552-559.

National Wetlands Working Group. 1997. The Canadian wetland classification system. 2nd edition. Warner BG, Rubec CDA editors. Wetlands Research Centre, University of Waterloo, Waterloo, Ontario.

Nunez-Mir GC, Iannone III BV, Curtis K, Fei S. 2015. Evaluating the evolution of forest restoration research in a changing world: a "big literature" review. New Forests 46:669-682.

OECD (Organisation for Economic Co-operation and Development). 2016. Biodiversity offsets: effective design and implementation. OECD Publishing, Paris. Available from https://doi.org/ 10.1787/9789264222519-en (accessed May 2016).
Pickett STA, Cadenasso ML. 1995. Landscape ecology: spatial heterogeneity in ecological systems. Science 269:331-334.

Quétier F, Lavorel S. 2011. Assessing ecological equivalence in biodiversity offset schemes: key issues and solutions. Biological Conservation 144:2991-2999.

Ramsar Convention. 1971. Canada 28: Beaverhill Lake, Alberta, information sheet on RAMSAR wetlands. Available from https://rsis. ramsar.org/RISapp/files/RISrep/CA370RIS.pdf (accessed September 2016).

Rayment M. 2014. Study on specific design elements of biodiversity offsets: biodiversity metrics and mechanisms for securing long term conservation benefits. A report submitted by ICF Consulting Services in association with IEEP and associated experts. Institute for European Environmental Policy, London. Available from http://ec.europa.eu/environment/nature/biodiversity/nnl/pdf/ Biodiversity\%20offsets\%20metrics\%20and\%20mechanisms.pdf (accessed February 2017).

Ruhl JB, Salzman J, Goodman I. 2009. Implementing the new ecosystem services mandate: a catalyst for advancing science and policy. National Wetlands Newsletter 31:11-20.

Serran JN, Creed IF. 2016. New mapping techniques to estimate the preferential loss of small wetlands on prairie landscapes. Hydrological Processes 30:396-409.

Strathcona County. 2006. Strathcona County Municipal Development Plan Bylaw 1-2007. Available from http://www.strathcona.ca/ departments/planning-development-services/zoning-and-planningdocuments/municipal-development-plan-bylaw-1-2007/ (accessed July 2017).

Suding K, et al. 2015. Committing to ecological restoration. Science 6235:638-640.

Thomas R, Lamb Z. 2005. Compensatory wetland mitigation and the watershed approach: a review of selected literature. Wetland Science and Practice 22:61-70.

UNESCO (UN Educational, Scientific and Cultural Organization). 2016. Beaver Hills. Available from http://www.unesco.org/ new/en/natural-sciences/environment/ecological-sciences/ biosphere-reserves/europe-north-america/canada/beaver-hills/ (accessed September 2016).

Waz A, Creed IF. 2017. Automated techniques to identify lost and restorable wetlands in the Prairie Pothole Region. Wetlands 37:1079-1091

Weber M, Hauer G, Farr D. 2015. Economic-ecological evaluation of temporary biodiversity offsets in Alberta's boreal forest. Environmental Conservation 42:315-324.

White D, Fennessy S. 2005. Modelling the suitability of wetland restoration potential at the watershed scale. Ecological Engineering 24:359-377. 